DOI: $10.26693 / \mathrm{jmbs} 03.06 .095$

UDC 612.766.1-057.87:004.946.5-042.72

Gordienko P. O., Pandikidis N. I., Shenher S. V.

\title{
A STUDY OF INFLUENCE OF WORKING AT THE COMPUTER ON SOME INDEXES OF THE PHYSICAL HEALTH STATE OF STUDENTS
}

\author{
Kharkiv National Medical University, Ukraine
}

pandikidis-n@ukr.net

The purpose of the work is to study the level of physical health, ability to work dynamics during the week, prevalence of Internet addiction and the impact of working at a computer on the students' health state.

Material and methods. To determine the level of sophomores' physical health we measured it by the indexes of Quetelet, Robinson, Skybinskiy, Shapovalova and Ruffie. The measurement was carried out at the beginning and at the end of the fall semester.

The study involved 22 students, 12 girls and 10 boys aged 17-19. Having evaluated each indicator in points according to the charts, we calculated the students' physical health level.

To determine the dynamics of ability to work level within a week for students who do not work with the computer and to determine the changes in $A, P, Q, S$, the testing was carried out in 20 minutes of work at the computer.

While determining students medical health state it was found out that the day of the greatest work capacity was Wednesday, and the day of the lowest work capacity was Monday.

According to our study, $14 \%$ of students had a low health level. The latter is characterized by a decrease in the level of protective forces, reduction of functional reserves, which can lead to the development of various disadaptation syndromes. Only $14 \%$ of the surveyed students had a high or above average level of physical health, but with a tendency to reduce it. The average level of health had $36 \%$ of students. Girls had lower physical health state indicators.

Twenty-minute work at the computer caused decreased indicators of students' mental capacity: overstrain of the central nervous system and the visual analyzer, decrease of the ability to concentrate attention, and decrease in the mental productivity coefficient, which characterizes the mobility of nervous processes. The obtained results proved that optimal time for working at a computer in accordance with mental capacity indicators made up 20 minutes.

Keywords: students, internet-dependence, computer, health indicators, ability to work.
Research relation to the plans, programs and department themes. The study was carried in accordance with the research work "Features of integrative and vegetative functions in the process of adaptation to intellectual, emotional and physical load", state registration number $0115 \mathrm{U} 000239$.

Introduction. Scientific and technical progress and its achievement change the surrounding world. These changes can have both positive and negative character, but they are always irreversible. So, with the appearance of computers and the Internet humanity passed to the new stage of civilization development. The Internet entered all areas of life deeply enough. Lately there has appeared a problem that psychologists call "Internet-dependence".

Regarding to problematic character of this dependence, we chose it to be our research topic. The question remains acute due to the fact that in literature there is no common opinion as to influence of computers on young people.

In this paper we tried to analyze prevalence of internet-dependence and influence of work at the computer on the state of students' health.

To achieve the aim it was necessary to fulfill the following tasks:

1. To review scientific and methodical literature on this question;

2. To conduct the anthropometric measuring of students at the beginning and in the end of fall semester: in September and in January;

3. To analyze the dynamics of capacity level within a week for the students of medical university who do not work at the computers;

4. To learn the changes of indexes $A, P, Q, S$, after 20 min of working at the computer.

"Internet-dependence" is a term that was first offered by the well known American doctor Goldberg a few years ago. He defined this concept as the insuperable addiction to the Internet characterized by the "ruinous operating on domestic, educational, social, working, financial areas of activity". Internet- dependence reminds a train to the narcotic substances, 
alcoholic beverages or gaming after the measure of removal from the real world.

Internet-dependence appears in those people who give advantage to life on the Internet, that actually begin to renounce the "real" life [1], conducting to 18 hours a day in virtual reality and not less than 100 hours a week $[3,4,5]$.

In expansion of symptomatology the specialists got interested in psychical health of patients and started researching this phenomenon $[8,9,11,12,15,16]$.

The purpose of the research was to study the level of physical health, ability to work dynamics during a week in sophomores of Kharkiv national medical university.

Material and methods. In order to gain the aim of the research we conducted the most informative and closely correlating measurements with the size of maximal consumption of oxygen and testing energy potential. To determinate the physical health of sophomores we measured the following indexes:

1. Quetelet index $=$ weight $(\mathrm{g}) /$ height $(\mathrm{cm})$

2. Robinson index $=$ heart rate (beat per minute) *Arterial pressure/100 (CU)

3. Skybinskiy index = vital capacity of lungs $(\mathrm{ml})$ *time of holding on inhalation/ heart rate (beat per minute)

4. Shapovalova index $=$ weight $(\mathrm{g}) /$ height $(\mathrm{sm})$ *amount of inclinations for 1 minute/60 (CU)

5. Ruffie index $=4(P 1+P 2+P 3)-200 / 10(C U)$

Measuring was conducted at the beginning (in September) and at the end of fall semester (January). 22 students took part in our research: 12 girls and 10 boys aged 17-19.

After the estimation of every index on tables in points, we determined students' physical health level:

- 2-7 points - low;

- 8-10 points - low middle;

- 11-15 points - middle;

- 16-20 points high middle;

- 21- 25 points - high.

We also conducted testing to determinate the dynamics of capacity level within a week for students who do not work at the computer and to determine the change of indexes $A, P, Q, S$, in 20 min of work at the computer.

Measuring was conducted on Monday, Wednesday, Thursday, and Friday with long breaks between periods for students, who do not work at the computer. For students who work at the computer this procedure was conducted on Wednesday after the second period and in $20 \mathrm{~min}$.

Results and discussion. The research showed that low values of Robinson index were significant especially for girls, which testified to certain violations in the cardiac activity and vascular system (Figure 1). Values of Skybinskiy index were high among boys

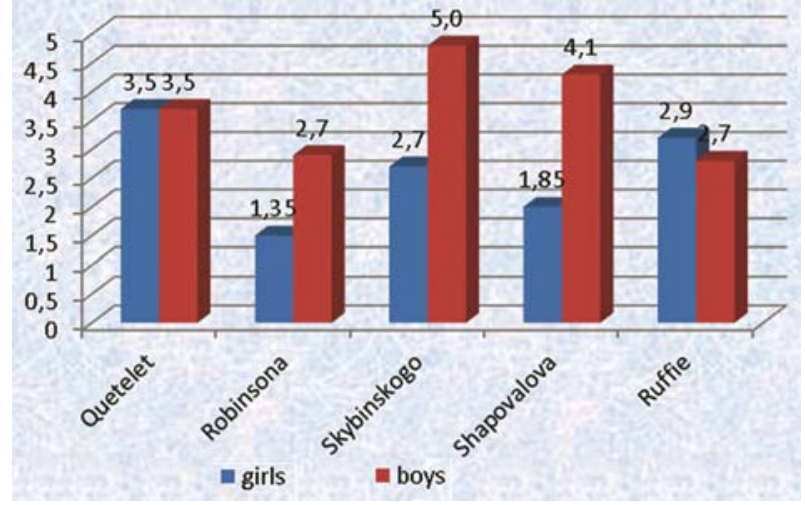

Figure 1. Indexes for the boys and girls

and low among girls. These values made it possible to talk about the decline of functional descriptions of the respiratory system organs and system of blood circulation. This can also be a risk of organism's inclination to hypoxia. Values of Shapovalova index were the following: high enough for boys and low for girls. This fact can testify to weak development of motive internals, like strength, speed and endurance. This can as well testify to the insufficiency of functional possibilities of the cardiac and respiratory system in girls.

Middle Ruffie indexes testify that to the middle level of adaptation backlogs of the cardiac and vascular system, organs of breathing that limits physical possibilities of the examined students.

Comparison of an express test results among girls showed that in January the Quetelet index grew from 3.5 to 4.4 points that specifies on the increase of body weight, which is connected to the reduction of physical activity of girls. Values of Robinson and Shapovalova indices did not change. Considerable enough is the reduction of the Skybynskiy index. It decreased from 2.7 to 1.9 points which could testify the possible decline of functional descriptions of the respiratory system and blood circulation system organs, and the in crease of organism's inclination to hypoxia (Figure 2).

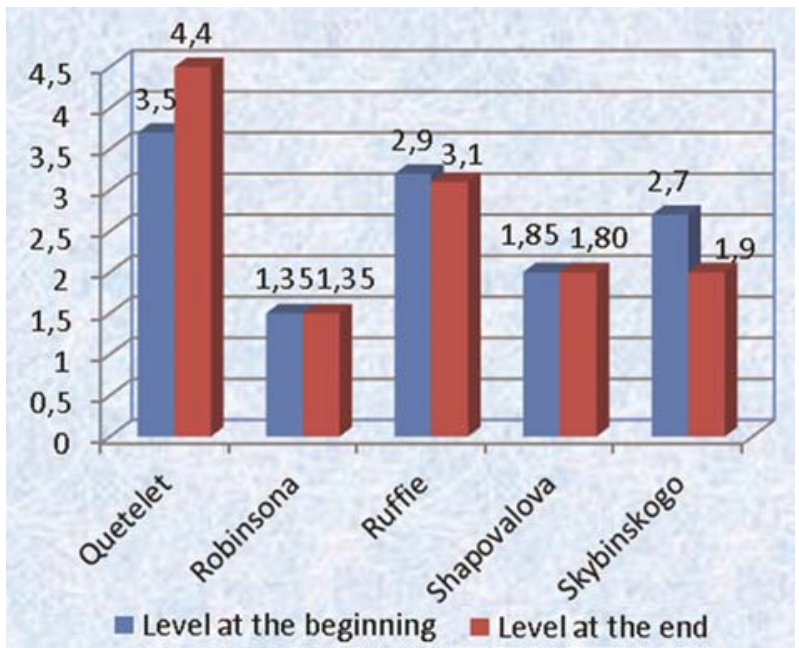

Figure 2. Indexes for the girls 
For boys the Skybinskiy and Quetelet indices almost did not change between the first and the second measuring. We can explain this fact by the difference in physical activity of girls and boys and by its character. An insignificant change can be marked in the Shapovalova and Robinson indices, which can testify to the decline of physiology backlogs of cardiovascular system and breathing organs (Figure 3).

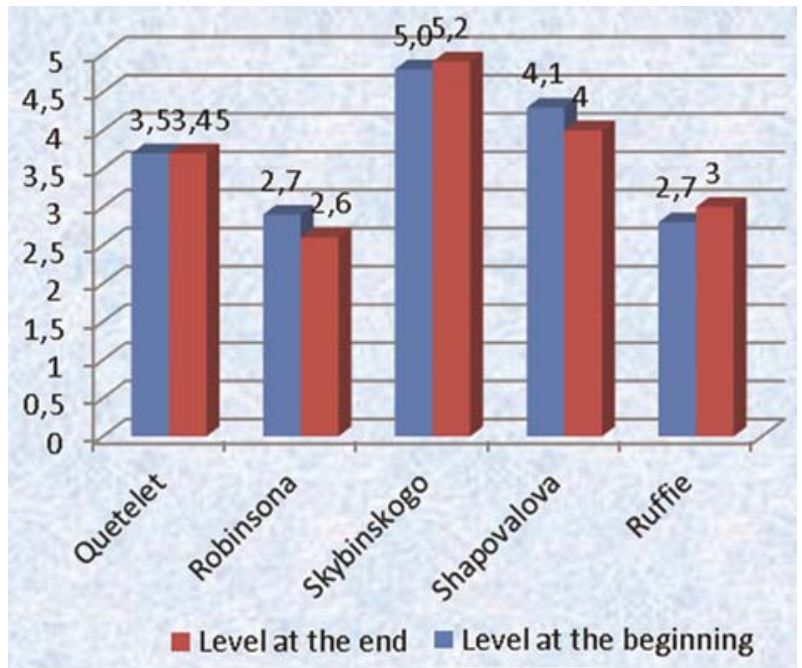

Figure 3. Indexes for boys

In general, there is a characteristic but insignificant reduction of Robinson, Shapovalova, Ruffie, and Skybinskiy indices and increase of Quetelet index.

According to the research results, there was a decline in the amount of physical health marked in 10 students of the entire group (45.5\%).

Physical health level did not change in $18 \%$ of students and increased in $31.8 \%$ of the examined.

The results of express estimation of students' physical health in September had the following values: high and low physical health levels were in $14 \%$ of students, high middle and middle - in $36 \%$ of students. At the end of the term (in January) these indices did not significantly change.

Dynamics of students' mental capacity indices under the influence of the educational process and work at the computer

The conducted research showed the following dynamics of capacity of the examined students during a week:

Coefficients of $Q$ (volume of visual information), $S$ (speed of processing the information), A (exactness), $\mathrm{P}$ (mental productivity) were the highest in the second half of Wednesday and in the first half of Thursday, and the least - on Monday. In our opinion, it is related to the gradual increase of capacity to the middle of the week and development of tiredness till the end of the week.

The obtained results showed that Wednesday appeared to be the day of the highest capacity for work. Therefore, we chose Wednesday for further testing of students who work at the computers with the optimal time for mental activity - the second period.

Change of $A, P, Q, S$ indices are in Figure 4 and 5.

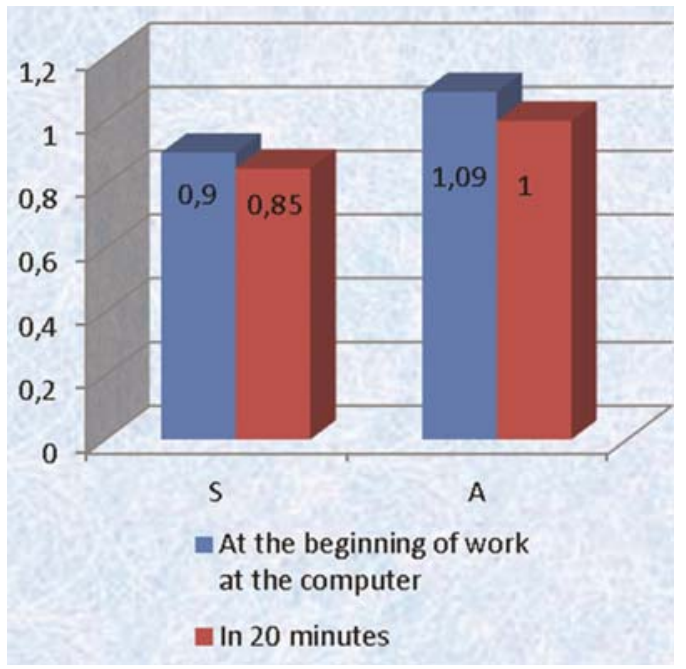

Figure 4. Dynamics of $A$ and $S$ indices changes during work at the computer

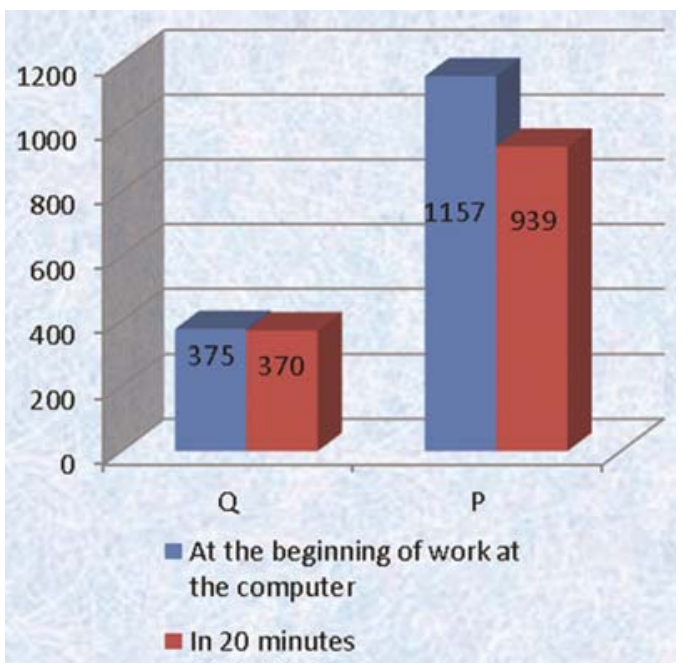

Figure 5. Dynamics of changes of $Q$ and $P$ indices during work at the computer

The coefficient of speed of processing of information (S) is decreasing (Figure 4), that testifies to the central nervous system (CNS) overstrain and braking of mental processes. As a result $S$ decreases from 0.9 to 0.85 . The coefficient of accuracy of the job processing $(A)$ is decreasing from 1.09 to 1.00 . Thus, there is an increase of amount of mistakes. This index testifies to the appearance of students' capacity decline and the first signs of tiredness appearing with it.

Figure 5 shows decline of visual information volume index (Q) from 375 to 370 . Thus, the amount of signs that were seen has decreased. Decreasing of 


\section{Медичні науки}

the coefficient of mental productivity $(P)$ is from 1157 to 939 , which characterizes motion of nervous processes and testifies to the considerable decline of the focusing attention. As, first of all, work at the computer affects visual analyzer characteristics of, we conducted the test called "Intortus lines". According to our results, in 20 min of works at the computer the common amount of the lines which were looked over decreases in average from 11 to 8 and amount of right answers from 5 to 3 . Reduction of the amount of the overlooked lines (Figure 6) was also noticed in the first and second testing. It decreased in average from 11 to 6 . This index is testified to general fatigue; overstrain of CNS and visual analyzer, the decline of ability to concentrate attention. The common amount of mistakes was calculated in per cents in the first and second testing. The chart shows (Figure 7), that it grew from 49.5 to 75.5 . The latter testifies to the decline of intellection, attention focusing and general tiredness. It is therefore possible to draw conclusion that optimal time of work at the computer is $20 \mathrm{~min}$ utes.

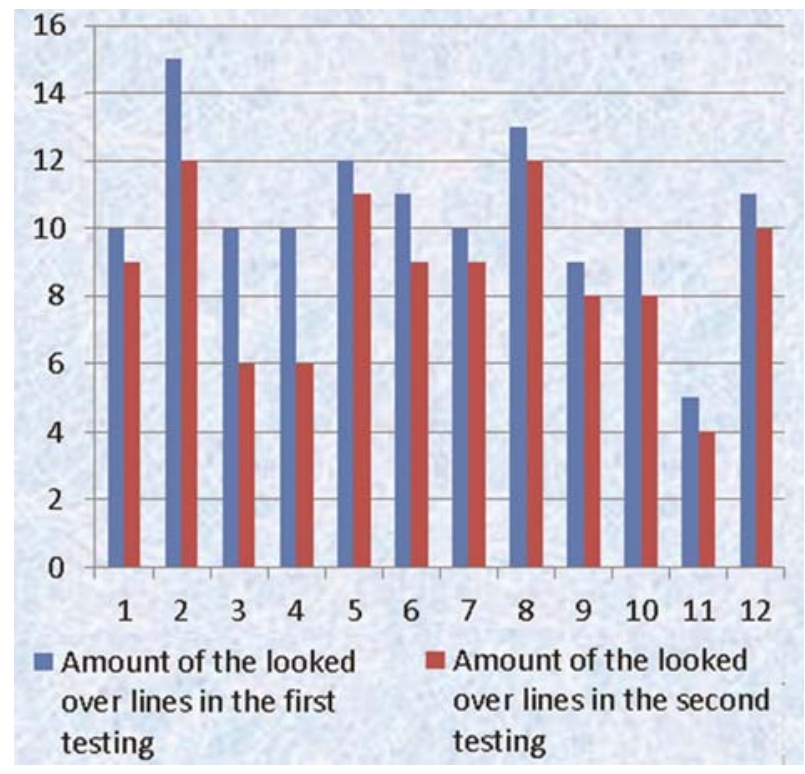

Figure 6. Amount of the overlooked lines in the first and second testing

Conclusions. While determining the state of health of sophomores of KNMU we came to the following conclusions:

1. A day of most capacity for students' work is Wednesday, and the day of the least capacity is Monday.

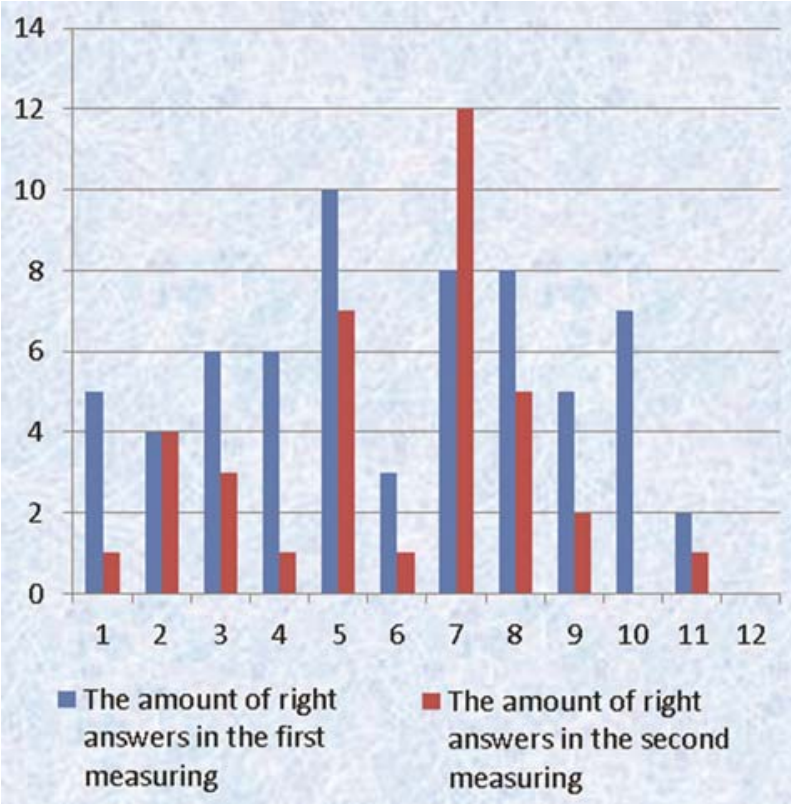

Figure 7. Right answers of the first and second measuring

2. 14 examined students have low level of health that is characterized by the decline of level of protective mechanisms, reduction of functional backlogs, which can result in diseases. With the aim of prophylaxis of diseases for these students it is necessary to stick to sparing regime, to watch and improve the diet, stick to the healthy life style.

3. Only 14 examined students had high or high-middle physical health level, and as research showed, tendency is marked to its decline. Thus, it is necessary to form valued relation of students to the own health.

4. A middle health level is marked in 36 students. Girls have lower indices. That is why they have to turn special attention to their way of life.

5. 20 minutes work at the computer caused reduction of students' mental capacity indices: overstrain of CNS and visual analyzer, the decline of ability to concentrate attention, decreasing the coefficient of the mental productivity that characterizes mobility of nervous processes.

6. To prevent the overstrain during work at the computer it is necessary to stick to the hygienic rules of using a computer, have necessary equipping, apartments, sentinel regulation.

7. Optimal time of work at the computer is 20 minutes according to the indices of mental capacity.

Prospects for further research. Further research will be dedicated to studying the impact of Internet addiction on the state of physical health and work capacity of students at different time intervals.

\section{References}

1. Burova VV. Sotsyalno-psykhologycheskye aspekty Ynternet-zavysymosty. M, 2001. 32 s. [Russian]

2. Voyskunskyy AE. Zavysymost ot Ynterneta: aktualnaya problema. Myr Ynterneta. 2000; 3: 76-81. [Russian] 
3. Voyskunskyy AE. Psykhologycheskye yssledovanyya fenomena Ynternet-addyktsyy. M, 2000. s. 62-3. [Russian]

4. Yang KS. Diagnoz - Internet-zalezhnist. Myr Interneta. 2000; 2: 36-43. [Ukrainian]

5. Young KS, O'Mara J, Buchanan J. Cybersex and Infidelity Online: Implications for Evaluation and Treatment -107 th annual meeting of the American Psychological Association, August 21, 1999.

6. Voyskunskyy AE. Psykhologycheskye yssledovanyya fenomena Ynternet-addyktsyy. M, 2000. 75 s. [Russian]

7. Gygyena. Rumyantsev GY, Ed. Uchebnyk dlya VUZov. M: Gelyos; 2000. 305 s. [Russian]

8. Datsenko YM. Gigiyena ta ekologiya lyudyny. K; 2000. 300 s. [Ukrainian]

9. Gygyena. Rumyantsev GY, Ed. Uchebnyk dlya VUZov. M: GEOTAR-MED; 2001. 608 s. [Russian]

10. Khrypkova AG, Kolesov DV. Gygyena y zdorove shkolnyka. M: Prosveshchenye; 1997. 156 s. [Russian]

11. Podolyak-Shumylo NG, Poznanskyy SS. Shkilna gigiyena: Navch posibnyk dlya pedagogichnykh instytutiv. Kyiv: Vyshcha shkola; 1981. 176 s. [Ukrainian]

12. Metodyky dyagnostyk. Praktycheskoe posobye. Kharkov: KhNU; 2002. 202 s. [Russian]

13. Shevchuk LT. Problemy formuvannya zdorovogo sposobu zhyttya molodi. Zdorovyy sposib zhyttya: zb nauk st. L: PP Borlak; 2006. Vyp 10. 236 s. [Ukrainian]

14. Kultura zdorov'ya. Zbirnyk naukovykh prats. Kherson: PP Vyshemyrskyy VS; 2006. 274 s. [Ukrainian]

15. Vsemyrnyy doklad o znanyyakh dlya luchshego zdorovya. Zheneva: VOZ; 2005. $41 \mathrm{~s}$. [Russian]

16. Sukharev AG. Zdorove y fyzycheskoe vospytanye detey y podrostkov. M: Medytsyna; 1991. 272 s. [Russian]

17. Trcha SV. Yskusstvo vesty zdorovyy obraz zhyzny. M: Medytsyna; 1986. 184 s. [Russian]

18. Kutsenko GY, Kononov YF. Rezhym dnya shkolnyka. M: Medytsyna, 1998. 206 s. [Russian]

19. Available from: http://www. health.ua

20. Available from: http://www.moz.gov.ua

удк 612.766.1-057.87:004.946.5-042.72

ВИВЧЕННЯ ВПЛИВУ РОБОТИ ЗА КОМП'ЮТЕРОМ НА ДЕЯКІ ПОКАЗНИКИ СТАНУ ФІЗИЧНОГО ЗДОРОВ'Я СТУДЕНСЬКОЇ МОЛОДІ

Гордієнко П. О., Пандікідіс Н. І., Шенгер С. В.

Резюме. Мета роботи - вивчити рівень фрізичного здоров'я, динаміку працездатності протягом робочого тижня, поширеність інтернет-залежності та впливу роботи за комп'ютером на стан здоров'я студентської молоді.

Методи дослідження. Для визначення рівня фізичного здоров'я студентів вимірювали індекси Кетле, Робінсона, Скибінського, Шаповалової, Руф'є. Вимірювання проводились на початку (у вересні) та наприкінці осіннього навчального семестру (січень). У дослідженні брало участь 22 студента - 12 дівчат та 10 хлопців 17-19 років. Після оцінки кожного показника по таблицях в балах розраховували рівень фізичного здоров'я студента. Для визначення динаміки рівня працездатності протягом тижня у студентів, які не працювали за комп'ютером, та для визначення зміни показників $\mathrm{A}, \mathrm{P}, \mathrm{Q}, \mathrm{S}$, було проведено тестування через 20 хв. роботи за комп'ютером. В результаті проведених досліджень було встановлено, що день найбільшої працездатності студентської молоді - середа, а найнижчої - відповідно понеділок. Вивчення показників фрізичного здоров'я показало, що 14\% досліджуваних студентів мають низький рівень здоров'я, який характеризується зниженням рівня захисних сил, зменшенням функціональних резервів, що може привести до захворювань. Лише у 14\% обстежених студентів відмічено високий або вище середнього рівень фрізичного здоров'я, але з тенденцією до його зниження. Середній рівень здоров'я відмічається у $36 \%$ опитуваних. Нижчі показники мають дівчата. Двадцяти хвилинна робота за комп'ютером викликала зменшення показників розумової працездатності студентів: перенапругу ЦНС та зорового аналізатора, зниження здатності концентрувати увагу, падіння коефіцієнту розумової продуктивності, який характеризує рухливість нервових процесів. Оптимальний за показниками розумової працездатності час роботи за комп'ютером, за нашими даними, становить 20 хвилин.

Ключові слова: студентська молодь, інтернет-залежність, комп'ютер, показники здоров'я, працездатність.

УДК 612.766.1-057.87:004.946.5-042.72

ИЗУЧЕНИЕ ВЛИЯНИЯ РАБОТЫ ЗА КОМПЬЮТЕРОМ НА НЕКОТОРЫЕ ПОКАЗАТЕЛИ СОСТОЯНИЯ ФИЗИЧЕСКОГО ЗДОРОВЬЯ СТУДЕНЧЕСКОЙ МОЛОДЁЖИ

Гордиенко П. А., Пандикидис Н. И., Шенгер С. В.

Резюме. Цель работы - изучение уровня физического здоровья, динамики трудоспособности на протяжении рабочей недели, распространенности интернет-зависимости и влияния работы за компьютером на состояние здоровья студенческой молодежи. 


\section{Медичні науки}

Методы исследования. Для определения уровня физического здоровья студентов 2 курса нами были проведены измерения индексов Кетле, Робинсона, Скибинского, Шаповаловой, Руфье. Измерения проводились в начале и в конце осеннего учебного семестра.

В исследовании принимало участие 22 студента - 12 девушек и 10 ребят 17-19 лет.

После оценки каждого показателя по таблицам в баллах, рассчитывали уровень физического здоровья студента.

Для определения динамики уровня трудоспособности на протяжении недели у студентов, которые не работают за компьютером и для определения изменения показателей $\mathrm{A}, \mathrm{P}, \mathrm{Q}, \mathrm{S}$, было проведено тестирование через 20 мин. работы за компьютером.

При определении состояния здоровья у студентов-медиков было установлено, что день наибольшей трудоспособности - среда, а день наиболее низкой трудоспособности соответственно понедельник.

По данным нашего исследования $14 \%$ студентов имели низкий уровень здоровья, который характеризовался снижением уровня защитных сил, уменьшением функциональных резервов, что может привести к развитию различных дезадаптационных синдромов. Лишь 14\% обследованных студентов имели высокий или выше среднего уровень физического здоровья, но с тенденцией к его снижению. Средний уровень здоровья отмечался у $36 \%$ опрошенных. Более низкие показатели физического здоровья имели девушки.

Двадцатиминутная работа за компьютером вызвала уменьшение показателей умственной трудоспособности студентов: перенапряжение ЦНС и зрительного анализатора, снижение способности концентрировать внимание, падение коэфффициента умственной производительности, который характеризует подвижность нервных процессов.

Оптимальное время работы за компьютером в соответствии с показателями умственной трудоспособности, по нашим данным, составляет 20 минут.

Ключевые слова: студенческая молодежь, интернет-зависимость, компьютер, показатели здоровья, трудоспособность.

The authors of this study confirm that the research and publication of the results were not associated with any conflicts regarding commercial or financial relations, relations with organizations and/or individuals who may have been related to the study, and interrelations of coauthors of the article.

Стаття надійшла 11.06 .2018 р. Рекомендована до друку на засіданні редакційної коледії після рецензування 